\title{
The Second Round Of G3 Reports: Is Triple Bottom Line Reporting Becoming More Comparable?
}

W. Richard Sherman, J.D., LL.M., C.P.A., Saint Joseph's University, USA Lauren DiGuilio, Saint Joseph's University, USA

\begin{abstract}
This paper explores the extent to which adoption of the Global Reporting Initiative's G3 reporting framework makes the external reporting of a company's financial, environmental and social performance more comparable. This inquiry takes the form of analyzing the content of the published sustainability reports of well-known companies to compare and contrast the information communicated in these reports. Particular attention will be paid differences in the published content of the second round of $G 3$ reports between companies in the pharmaceutical industry.
\end{abstract}

Keywords: Sustainability Reporting; Triple Bottom Line Reporting; Corporate Social Responsibility

\section{INTRODUCTION}

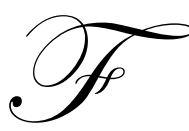

inancial success has long been accepted as the primary objective of corporate existence. However, many social critics have questioned whether financial success is enough. There are increasing demands that companies be good corporate citizens as well. Organizations struggle to tell their stories, to communicate the good (and sometimes the bad) that they do in the marketplace, in the community, to and for the environment, and in society. Quite clearly, the challenge of telling the company's story is not being met by current corporate reporting practices. In particular, criticism has been directed at the failure of annual reports or other regulatory files to tell anything about a company's environmental and social performance. Triple bottom-line (TBL) reporting, a term coined by John Elkington in his 1997 book Cannibals with Forks: the Triple Bottom Line of 21st Century Business, aims to remedy this shortcoming by explicitly considering not only the economic performance of a firm but also the company's environmental and social performance as well. An increasingly popular practice is the issuance of a corporate responsibility or sustainability report. The international accounting firm KMPG reviewed the disclosures of more than 2,200 companies, including the Global Fortune 250 and 100 largest companies in 22 countries. The KPMG International Survey on Corporate Responsibility Reporting (2008) found that 74 percent of the top 100 U.S. companies (as measured by revenue) published corporate responsibility information in 2008, either as part of their annual financial report or as a separate document. This was an increase from the 37 percent of top U.S. companies that KPMG surveyed in 2005. An even higher percentage of top international firms are reporting on their environmental and social performance with 80 percent of the Global Fortune 250 companies now releasing this information.

Despite this impressive increase in the issuance of sustainability reports, initial efforts at TBL reporting have been plagued by their lack of uniformity, consistency, and comparability in the information presented. The Global Reporting Initiative (GRI) has attempted to fill this void by developing a detailed framework that is intended to create an analog to the generally accepted accounting principles (GAAP) approach to financial reporting. Simply put, if companies use the same ground rules in preparing their sustainability reports, the information presented in those reports should promote greater comparability. This paper considers whether the use of the GRI G3 Framework does indeed make TBL reporting more comparable. In particular, it looks at the evolution of sustainability reporting through successive iterations of $G 3$ reports. 


\section{The G3 Guidelines}

Formed in 1997, the Global Reporting Initiative (GRI) clearly states its objective:

To enhance responsible decision making by promoting international harmonization in reporting relevant and credible corporate economic, environmental, and social performance information (GRI, 2002).

To this end, the GRI has developed and published reporting guidelines which follow the broad TBL reporting of economic, environmental, and social performance with the social grouping being further subdivided in terms of labor practices, human rights, society, and product responsibility. In an attempt to enhance comparability and auditability, the GRI issued its third generation (G3 Guidelines), in October 2006. The G3 framework modifies the 97 "key performance indicators" (KPIs) of the $G 2$ framework into 79 performance indicators (GRI, 2007). Fifty of these indicators are considered "core" because the GRI believes them to be of interest to most stakeholders and, consequently, they are "assumed to be material unless deemed otherwise on the basis of the GRI Reporting Principles" (GRI, 2006). One of the most significant aspects of these indicators is that some are quantitative (e.g. LA1: Total workforce by employment type, employment contract, and region) while others are qualitative (e.g. EC7: Procedures for local hiring and proportion of senior management hired from the local community) in nature. Furthermore, the quantitative indicators are expressed in various monetary and non-monetary units of measure.

In addition to these performance indicators, all $G 3$ reports must contain a GRI Content Index (Element 3.12) to alert readers to where in the sustainability report the standard disclosures can be found (GRI, 2006, p. 22). Furthermore, the organization should disclose the level of reporting it has chosen. The levels of reporting range from A through C. The GRI's rationale behind allowing differing levels of reporting is to encourage companies to ease their way into using the guidelines, even if they are not prepared to implement all the guidelines immediately. The level of reporting chosen can simply be self-declared, verified by an external third party, or checked by the GRI itself. Externally verified reports add a "+" to their level of reporting.

In response to criticism of the GRI's one-size-fits-all approach, the GRI has developed fifteen Sector Supplements for segments such as the apparel and footwear, financial services, and automotive industries. [See, for example, the GRI Automotive Sector Supplement (GRI, 2004) and the GRI Financial Services Supplement (GRI, 2009b).] These Sector Supplements are not intended as a replacement for the more general G3 framework but do address the more specific issues encountered by companies in particular industries.

While compliance with the Guidelines is entirely voluntary, more than 1,100 reports were officially registered with the GRI in 2009 (Ceres, 2010). More than three-quarters of the G250 and nearly 70 percent of the N100 use the GRI Guidelines for their reporting (KPMG, 2008) with the number of companies adopting the G3 guidelines increasing by $46 \%$ in 2008 (GRI, 2009a). Further evidence of the dominance of the GRI Guidelines can be found by the fact that $64 \%$ of companies listed on Germany's DAX 30, $48 \%$ of those listed on France's CAC 40 , and $22 \%$ of the UK's FTSE 100 say they use the GRI guidelines (Ceres, 2010).

\section{METHODOLOGY}

This study takes the form of analyzing the content of the published sustainability reports of well-known companies to compare and contrast the information communicated in these reports. Content analysis is particularly appropriate for sustainability disclosures. Pedrini (2007) uses content analysis to investigate the points of convergence between intellectual capital and corporate responsibility reports prepared under the GRI's 2002 Guidelines. Clarkson et al (2008) develop a content analysis index to test the environmental disclosure under the 2002 Guidelines.

Sherman $(2008 ; 2009)$ expands beyond the GRI's recommended environmental and intellectual capital disclosures and examines the extent to which companies present the kind of information that the G3Guidelines recommend for all aspects of an organization's TBL performance. He found difficulty in comparing the information presented in the first wave of $G 3$ Reports of Ford and Volkswagen in the automotive industry, Citigroup and Barclays in financial services, Merck and Bayer in pharmaceuticals, and Nike and Adidas in the sporting goods industry (Sherman, 2009). 
As a first step, this study looks at the progression of reporting by these eight companies in their second or third iteration of $G 3$ reports. The particular companies studied are selected quite intentionally. First of all, these are highly visible companies. More significantly, all have reputations for being good corporate citizens and have received awards and other recognition for the reporting of their non-financial performance. All prepare sustainability reports using the $G 3$ Guidelines. Given these common characteristics, one would expect a greater comparability between and among the companies which is one of the paramount goals of the G3 Guidelines. Indeed, one of the greatest challenges in evaluating the value that is being added by the content in these disclosures is the extraordinarily wide variability in the form of the disclosures.

While variability in the content of the disclosures is expected due to the differing materiality of issues which a company faces, one would expect less variability in content from companies operating in the same industry. In other words, those companies operating in the same industry face similar challenges to their corporate responsibility. To explore this aspect further, this study focuses on the G3 reports of companies in the pharmaceutical industry.

Some important differences in the companies' TBL disclosures may also be expected related to the company's geographic base. There is a general perception that European-based companies are more sensitive to issues of sustainability than are U.S.-based organizations. Indeed, the GRI found that of the more than 1,500 sustainability reports of which it is aware, $49 \%$ were issued by European companies. North American companies represent only 14\% (GRI, 2009). Consequently, it will be interesting to see if this perception is confirmed by the reporting of European companies as compared and contrasted to that of American firms.

After considering the progress (or lack thereof) of the eight companies, spanning four industries, this analysis will take a closer look at the measure used by companies in the pharmaceutical industry. By looking at some of the more objective $G 3$ performance indicators, a better understanding of the comparability of disclosures can be achieved.

\section{ANALYSIS}

\section{Ford vs. Volkswagen}

Ford and Volkswagen share the same challenges to their responsible corporate citizenship that other companies in the automotive industry face. The primary issue is that of greenhouse gas emissions and how the cars and trucks they manufacture contribute to climate change. One would therefore expect Ford and Volkswagen to set similar goals, follow aligned approaches, and report comparable data. These expectations are disappointed.

Both companies have reported at the A level in their first two G3 reports. While both companies now disclose information on $90 \%$ of the core performance indicators, there are discrepancies between which indicators are reported. In their first G3 reports, issued for 2007, Ford and VW reported on $70 \%$ common indicators (Ford, 2008b; VW, 2008). This improved to 82\% in their second iterations for 2009 (Ford, 2010b; VW, 2010). This improvement should lead to greater comparability. However, even when a common goal is stated (e.g. reduction of $\mathrm{CO}_{2}$ ), the scale of the reduction is not comparable. While Ford states it plans to reduce the $\mathrm{CO}_{2}$ emissions of its new US and EU vehicles by $30 \%$ by 2020 (Ford, 2008a, p. 3), Volkswagen does not set $\mathrm{CO}_{2}$ goals for its US or EU vehicles, but targets a $20 \%$ reduction in fuel use and $\mathrm{CO}_{2}$ emissions in China (Volkswagen, 2008, p.74). Interestingly, the greatest divergence of disclosure between the two companies is in the core environmental performance indicators. As noted above, Ford discloses some information (partial or complete) for 16 of the 17 for both years; VW discloses information on 12 in its 2007 report; on 15 in 2009. Particularly in their first G3 reports, the companies are not even disclosing the information on the same indicators. Six of the environmental indicators are reported by one company but not the other, leaving 11 common indicators on which some information is provided. Given that both companies use the same G3 Guidelines and both companies report at the A level, this is particularly disappointing. One would and should expect greater comparability. Based upon the $G 3$ disclosures, it is impossible to conclude which company is performing more responsibly in addressing the critical challenge to its industry. 


\section{Citigroup vs. Barclays}

Given the B level of reporting chosen by both Citigroup and Barclays, the relatively lower level of disclosure is expected when compared to the A level sustainability reports issued by Ford and VW. Following the GRI's rationale in allowing these different reporting levels as a way to ease into the G3 Guidelines, one would hope that in future years, the companies would increase their TBL reporting to encompass more information about their non-financial performance. That notwithstanding, because both Citigroup and Barclays report at the same level, a meaningful comparison of the reports should be possible. While both companies now report on $40 \%$ of the total core performance indicators (Citigroup, 2009; Barclays, 2009), the comparability of the two banks is impaired by the fact they only disclose information on 26\% of the same indicators in their first G3 reports (Citigroup, 2008b; Barclays, 2008c). This drops to $20 \%$ in their second G3 reports (Citigroup, 2009; Barclays, 2009).

The issue that received the most discussion in the Citi's first $G 3$ report is the environment. Therefore, it is not surprising that Citi provides information on twice as many of the $G 3$ environmental core indicators as does Barclays -8 vs. 4 in their 2007 reports (Citigroup, 2008b; Barclays, 2008c); this difference increases in their sustainability reports for 2008, with Citi reporting on nine of the core environmental performance indicators while Barclays discloses information on only three (Citigroup, 2009; Barclays, 2009). On the other hand, there is no apparent difference in the emphasis that the companies place on Labor Practices \& Decent Work in the narratives of their respective reports. Consequently, it is curious that Barclays reports on eight of the core indicators in that area (dropping to six indicators in its 2008 report) while Citi only provides information on three (dropping to two in its 2008 report). There does not seem to be anything particularly unusual about the indicators on which Barclays reports but Citi does not [viz. LA1: Total workforce by employment type, employment contract, and region; LA2: Total number and rate of employee turnover by age group, gender, and region; LA3: Benefits provided to full-time employees that are not provided to temporary or part-time employees; LA5: Minimum notice period(s) regarding operational chances; LA7: Rates of injury, occupational diseases, lost days, and absenteeism, and number of workforce fatalities by region; LA14: Ratio of basic salary of men to women by employee category] which would explain the discrepancy. Another interesting difference is that Barclays provides information on three core indicators in 2008 (two in 2009) in the area of human rights which Citi reports as being non-material to its operations. This additional disclosure may be more a function of Barclays leadership role in human rights initiatives (e.g. it is one of 14 corporations which form the Business Leaders Initiative on Human Rights) than it is a reflection of Citi's understatement of the impact on human rights in its business (Barclays, 2008c).

\section{Merck vs. Bayer}

The primary difficulty in comparing the Merck and Bayer reports does not stem so much from the different level of reporting chosen by the companies (Merck at the B level; Bayer at the A+ level) as from the different units of measures used. Indeed, Merck's reporting of $82 \%$ in 2007, increasing to $86 \%$ in 2009, of the core performance indicators was only slightly lower than Ford's at $84 \%$ and was higher than the $78 \%$ reported by VW in their first $G 3$ reports - and this in spite of the fact that the two car companies report at the A level (Bayer, 2008a; Merck, 2007a). Moreover, the two pharmaceutical companies have $80 \%$ common performance indicators in their first reports. This increases to $84 \%$ for their second iteration of G3 reports (Bayer, 2010; Merck, 2008a).

As just one example of the different units of measure, Bayer reports that its total energy use in 2007 was 91.7 petajoules (equivalent to 25.5 terawatt hours) in 2007; Merck reports its 2007 energy use as 15.2 million BTU x $10^{6}$ (Bayer, 2008g; Merck, 2007a). The information about energy usage is indeed being disclosed by both companies but is it comparable?

Because of the generally greater disclosure by these pharmaceutical companies, a closer look at the actual information being disclosed by other companies in the industry is warranted in a later section of this paper.

\section{Nike vs. Adidas}

From a corporate responsibility perspective, perhaps the greatest challenge for Nike, Adidas, and the global sporting goods and apparel industry is the management of their supply chain. The companies do not manufacturer 
the shoes, apparel, and equipment they sell under their brand-name. Instead the manufacturing of their products is subcontracted to factories, most of which are located in developing nations. Nike, for example, has only around 24,000 employees, the vast majority working in the United States. All other workers are employed by its independent suppliers. Nike estimates that of the 800,000 workers in its contract supply chain, $80 \%$ are women between the ages of 18 and 24 (Nike, 2007a, p. 16). Adidas has a very similar, if somewhat more geographically dispersed organizational structure (over 31,000 employees in 150 locations (Adidas, 2008a, p. 56)). Because they face the same corporate citizenship challenges, one would expect the companies' sustainability reports to provide a similar approach and similar information to communicate their efforts. Yet an analysis of the content of the two reports reveals disturbing inconsistencies in the way in which economic, social, and environmental performance is disclosed. The "footprint" (i.e., locations) of the companies suppliers is remarkably similar (Adidas, 2008a, p. 6263; Nike, 2007a, p. 25) yet the metrics used to measure performance are non-comparable. For example, Adidas has created a KPI (Key Performance Indicator) consisting of six units of measure (Adidas, 2008a, p. 36). While the company reports the average score in each of the units of measure, there is no way to interpret these data. Nike has a seemingly similar system of auditing the compliance of its suppliers with company policies but it reports the results of this compliance in very different terms than does Adidas (Nike, 2007a, pp. 30-32). In short, there is no way to conclude which company is doing a better job of managing its supply chain. Rather than presenting common denominators for comparison of the two companies' economic, environmental, and social performance, the disparity in the amounts and types of core performance indicators presented by Nike and Adidas make any comparison between the two companies meaningless.

It would be in precisely this situation that one would hope that use of the G3guidelines would promote greater comparability. However, in their first G3 reports, disclosure on the 50 core performance indicators is minimal. Nike reported on about half (48\%); Adidas on only 18\% (Nike, 2007b; Adidas Group, 2008b). Perhaps as disappointing is the companies reported on only $28 \%$ of common performance indicators. In its most recent sustainability report, Adidas no longer uses the $G 3$ guidelines (Adidas Group, 2010). Given the paucity of reported core performance indicators when Adidas was using the guidelines, there seems to be little loss since comparability with Nike's performance was so minimal.

\section{A Closer Look at the Pharmaceutical Companies}

In order to further investigate the comparability of the $G 3$ reports, this study takes a closer look at the actual data reported by companies in the pharmaceutical industry. Table 4 lists twenty of the fifty core indicators which were deemed to be the most objective and quantifiable. Table 5 lists the thirteen well-known pharmaceutical companies analyzed. It should be noted that 10 of these companies use the G3 Guidelines. Three companies Abbott, Johnson \& Johnson, and sanofi-aventis - do not actually prepare $G 3$ reports but do reference the $G 3$ and use the core performance indicators which they felt are most relevant to their operations. Given the commonality of the indicators disclosed, these companies were included in the sample despite the absence of formal implementation of the $G 3$ Guidelines.

A first level of comparability between and among these companies is represented by the common disclosures contained in their reports. Table 6 provides an overview of this comparability. For instance, all thirteen companies report on core indicators EC2 (financial implications and other risks and opportunities for the organization's activities due to climate change), EN3 (direct energy consumption by primary energy source), and EN16 (total direct and indirect greenhouse gas emissions by weight). There is also comparability in the disclosures that are "under-reported" by the companies. For example, only $38 \%$ of the companies provide information on EN2 (percentage of materials used that are recycled input materials) or LA2 (total number and rate of employee turnover by age group, gender, and region); only $23 \%$ of the pharmaceutical companies analyzed disclose information on LA14 (ratio of basic salary of men to women by employee category). Remembering that these indicators are considered "core" because the GRI believes them to be of interest to most stakeholders and, consequently, they are "assumed to be material unless deemed otherwise on the basis of the GRI Reporting Principles" (GRI, 2006), this non-reporting is somewhat surprising.

A second level of comparability is represented by the actual data being disclosed by the companies for each of the performance indicators. This analysis now looks at the information that is being reported for six of the core 
performance indicators - one in each of the major TBL categories.

\section{Economic}

EC1: Direct economic value-generated and distributed, including revenues, operating costs, employee compensation, donations and other community investments, retained earnings and payments to capital providers and customers

As noted in Table 6, 92\% of the companies selected for this study disclose information on EC1with sanofiaventis being the only company that does not report on this core performance indicator. However, how this information is disclosed is not the same for the other 12 companies. AstraZeneca (2008d) and Roche (2009b) merely reference their annual 10-K for information on this indicator; GlaxoSmithKline (2008c) and Pfizer (2008e) do not provide any concrete objective information. The remaining eight companies list fairly comparable information. All report information regarding their annual revenue figures. The disparity in the disclosure comes from what else is reported:

- Disclosure regarding employee compensation is covered in the G3 Reports of Abbott (2008a), Novartis (2008b), and Novo Nordisk (2009g).

- $\quad$ Disclosure regarding charitable contributions and philanthropy is included in the $G 3$ reports of Abbott (2008a; 2008b), Baxter (2008b) and Johnson \& Johnson (2008b).

- $\quad$ Disclosure regarding dividend and shareholder information is reported by Abbott (2008a), Baxter (2008b), Johnson \& Johnson (2008b), Merck (2008b), Novartis (2008b) and Novo Nordisk (2008g).

Other items reported under EC1 by Baxter (2008b), Johnson \& Johnson (2008b), Merck (2008b), Novartis (2008b) and Novo Nordisk (2008g) include the amount of value added to the government in the form of taxes. In addition, the reports of Bayer (2008b) and Merck (2008b) include information on how many are employed within the company, and Bristol-Myers Squibb (2008b) discloses the total number of its suppliers.

\section{Environmental}

EN28: Monetary value of significant fines and total number of non-monetary sanctions for non-compliance with environmental laws and regulations

Of the companies studied for further analysis, twelve of the thirteen companies reported information on EN28, with sanofi-aventis again being the only company not to disclose. Two of the companies, Abbott (2008a) and Bayer (2008g), reference the note regarding litigation in their Annual 10-Ks. Novo Nordisk (2009c) does not have an objective or quantifiable disclosure; instead, the company states that they will only report on noncompliance with environmental regulations, but on nothing that is not a legal issue. The remaining companies do disclose some information. Pfizer (2008c) and Roche (2009c) both report that there were no fines imposed for the most recent reporting year. Novartis disclosed the amount of fines it paid. The disclosure of the fines is the only place where comparability exists among all of the companies. There is a disparity among the companies in reference to which type of sanctions are reported. Baxter (2008d) discloses information regarding their number of violations for the past two years, as well as their environmental fines and environmental incidents over the span of 2005-2008. GlaxoSmithKline (2008b) and Merck (2008c) both provide information on the number of inspections performed; however, Merck goes further with releasing the amount of spills, safety notices, and violations of environmental matters.

\section{Social: Society}

SO1: Nature, scope, and effectiveness of any programs and practices that assess and manage the impacts of operations on communities, including entering, operating, and exiting

Sixty-nine percent (9 of the 13) of the companies disclose information on SO1. This is the performance indicator in which each company reports information that is relevant and important to their place in society. Because 
of this, it would be expected that the companies in this sample utilize this indicator in a variety of different ways. Roche (2009g) uses this indicator to disclose its continued philanthropic efforts. For GlaxoSmithKline (2008i), this indicator allows the company to disclose their contribution to the global health community. For sanofi-aventis (2008)), this disclosure creates an opportunity for further discussion in its research and development. Given the widely differing uses of this performance indicator, while the information may not be comparable on the basis of objectivity, it is comparable in the sense that it represents the goals and values of each company.

\section{Social: Human Rights}

HR2: Percentage of significant suppliers that have undergone screening on human rights and actions taken

Twelve of the thirteen (ninety-two percent) of the analyzed companies provide disclosures on HR2. The main purpose of this indicator is to show a percentage; however, for most the companies, the disclosure did not provide a very quantifiable number. Merck, Novartis and Novo Nordisk are the three companies which provided the most objective disclosures. Merck (2008d) includes information on the standards that their suppliers are expected to follow, as well as the surveys, including details on ethical, health and labor standards, that are sent to each of their suppliers. In $2008,81 \%$ of their suppliers completed this survey, and in $2007,54 \%$ complete this survey. Novartis (2008d) notes their number of significant suppliers (416, which represents $31 \%$ ) as the answer to the percentage that has undergone screening. Novo Nordisk (2009d) includes information about the consistency of the audits of their suppliers, and discloses that in 2009, 20 audits were performed, resulting in a number of critical findings. Many of the other companies have established that there are specific guidelines for the suppliers. For instance, Abbott (2008h) has Supplier Guidelines which emphasize the importance of fair competition and ethical working standards; it also discloses information regarding the amount of their suppliers owned by minorities, women and smallbusinesses. Bayer (2008f) enforces the Bayer Procurement Community Policy for its suppliers. Baxter (2008f) has quality and compliance standards with a focus on child labor, confidential and proprietary information, fair employment, and intellectual property. Baxter also assesses their suppliers for their sustainability programs. GlaxoSmithKline (2008h) and sanofi-aventis (2008b) both state that their suppliers are audited and evaluated. Johnson \& Johnson (2008d) places emphasis on global labor and child labor, and focuses on supplier diversity. Only one company - Bristol-MyersSquibb - does not report on HR2 with Roche (2009h) referring to the Annual Business Report for information regarding this disclosure.

\section{Social: Labor Practices \& Decent Work}

\section{LA1: Total workforce by employment type, employment contract, and region}

Of the eight companies that disclose statistics for LA1, six report in a very similar objective and quantifiable fashion. Of these six, all but one (Roche, 2009e) disclose information regarding the regional headcount. For example, Baxter (2008c), Bayer (2008d), and sanofi-aventis (2008c) list at least two years of data, broken out by the regions in which the company operates. Novartis (2008e) and Novo Nordisk (2009b) disclose the employee headcount for only 2009. Abbott (2008b) and Merck (2008e) are the two companies who disclose information on LA1, but are not comparable with the other companies. Abbott places their emphasis on having a diverse workforce, but does not provide any evidentiary support. Merck lists statistics regarding the number of women and ethnics groups that are employed, but nothing further.

\section{Social: Product Responsibility}

PR1: Life cycle stages in which health and safety impacts of products and services are assessed for improvement, and percentage of significant products and service categories subject to such procedures

All but one of the companies studied (Bristol-MyersSquibb) report on PR1. For a great majority of the companies who report on this indicator, product and patient safety are the main concern and are of greatest importance. Abbott (2008c), AstraZeneca (2008g), and Pfizer (2008f) report that they have an increased focus on research and development leading to a safe product. Bayer (2008j) lists responsible marketing as one of its tools to ensure product and patient safety. Instead of just focusing on the marketing aspect, some companies focus on the 
entire life cycle. For instance, Abbott (2008c) places heavy emphasis on assessing the regulation, manufacturing, and sales, marketing and distribution. Baxter (2008g) performs a two-step assessment, one high level and one comprehensive, across its products' life cycle. Roche (2009f) focuses on the promotion of patient safety throughout its supply chain. GlaxoSmithKline (2008e; 2008g; 2008j) performs audits of suppliers and works on anticounterfeiting methods. Johnson \& Johnson (2008e) perform evaluations from the level of the raw materials to ensure a safe product. Novartis (2008f) uses two methods - clinical trials and pharmacovigilance - to produce safe products. Novo Nordisk (2009e) discloses their focus on compliance with regulation and global standards, and also emphasizes the performance of audits and anti-counterfeiting methods.

A couple of the companies under study take a completely different route when disclosing on this indicator. For example, Merck (2008f) focuses on the safety in the workplace by listing a decrease in the lost-time rate. Sanofiaventis (2008d) includes information about its commitment to reduce the environmental impact for the entire life cycle of the drug, with optimization of packaging as its focal point.

\section{CONCLUSION}

One of the objectives of this study is to see how the sustainability reports using the G3 Guidelines evolve over successive iterations. Table 1 gives an overview of these companies originally studied by Sherman (2009). The rationale for permitting varying levels of reporting is to give organizations an opportunity to experiment with using the $G 3$ indicators without having to adopt them all at once. The hope is that companies will increase their level of reporting over time. With the possible exception of Nike (which did not state the reporting level of its 2007 G3 report), no company has increased its level of reporting. Adidas, on the other hand, no longer uses the G3 Guidelines at all. Nevertheless, even with no change in reporting levels, there was a general increase in the number of core performance indicators for which information is provided in the companies' second $G 3$ reports relative to their first $G 3$ reports. Adidas and Barclays are the two companies which report on fewer indicators the second time around. Table 3 summarizes these changes.

A growing trend in sustainability reporting is external verification of the reports (KPMG, 2008). However, among this limited sample, only Volkswagen, Barclays, and Bayer had external verified first reports. This did not change in the second iterations. A slightly higher proportion of the pharmaceutical companies studied (6 out of 13) opted for external verification of their sustainability reports.

A logical conclusion to reach is that by reporting on more of the core performance indicators (see Table 3) and by having a greater commonality in the indicators for which information is disclosed (see Table 2), comparability of sustainability reports is enhanced. However, as noted in the analysis of the individual pairs of companies, there is a disturbing lack of common measures of reporting the 50 core indicators. In order to address this issue, this analysis was extended to an expanded number of companies in a particular industry. More importantly, this study looks at the data behind the disclosures.

To further analyze the companies in the pharmaceutical industry, indicators that were expected to be the most quantifiable and objective were selected. An analysis of a sample of twenty core performance indicators leads to the conclusion that comparability of the information being disclosed varies significantly. For some indicators, the information reported is indeed comparable. However, this is certainly not the case for all of the indicators. In some cases, the units of measures pose an impediment to comparability. For example, while all of the selected pharmaceutical companies disclose information on EN3 (direct energy consumption by primary energy source), there is a lack of consistency in how this information is expressed in the reports. A variety of different units of measure are used by the companies. Four of the thirteen companies use "million gigajoules" as their unit of measure. Other units of measure employed include terajoules (Roche, 2009a)), petajoules (Bayer, 2008i), or gigajoules (sanofi-aventis, 2008a).

While the lack of comparability for some of the indicators can be remedied with a relatively simple conversion, for others, there is no easy fix. The information is simply not being disclosed in an objective and quantifiable fashion. This lack of objectivity is most noticeable in the social indicators, particularly in those related to Society and Human Rights. Because these are areas of TBL reporting in which each company reports information 
it believes is most relevant and important to its place in society, it is not surprising that the data presented are not comparable.

It has been the hope that with the further development and use of the G3 Guidelines, there would be an increased comparability among the sustainability reports of the companies using these guidelines. However, despite the fact that these companies are all within the pharmaceutical industry and, therefore, face similar challenges to their corporate citizenship, comparability among reports has not been fully enhanced by the GRI's core performance indicators. Moreover, there will probably always be difficulty of interpreting core performance indicators even when they are consistently disclosed. As one survey of sustainability reports concludes:

At the same time, the problem may arise from the lack of an established means of assessing sustainability information in reports. It might then be said that the reports provide "too much information, too little meaning" (KPMG \& SustainAbility, 2008, p. 29).

Is TBL reporting becoming more comparable? This study has been unable to answer that question definitively. While the G3 Guidelines do provide a common basis for reporting, there is still a long way to go before the equivalent of GAAP for sustainability reporting is established.

\section{AUTHOR INFORMATION}

W. Richard Sherman is a Professor of Accounting at the Saint Joseph's University's Haub School of Business in Philadelphia, Pennsylvania, USA. After receiving his Bachelor's degree Sociology, Rick earned his law degree (J.D.), an MBA with a concentration in Accounting, and a graduate degree in tax law (LL.M.). Recipient of numerous awards for excellence in teaching, research, and service, including the prestigious Christian \& Mary Lindback Foundation Award for Distinguished Teaching, Professor Sherman has published over 50 articles in academic and professional journals. His research spans issues in accounting education, tax, uses of accounting information, and sustainability reporting.

Lauren DiGuilio is an Associate in the Assurance Practice for PricewaterhouseCoopers, LLP, in Philadelphia. Lauren graduated from Saint Joseph's University in May 2010, with a Bachelor of Science degree in Accounting summa cum laude. She graduated with the highest Grade Point Average (GPA) in the Haub School of Business, earning both the distinguished honors of the Dean's Award and the Accounting Department Award.

\section{REFERENCES}

1. Abbott Laboratories (2008a). About Abbott (EC1.) http://www.abbott.com/global/url/content/en_US/40.10:10/general_content/General_Content_00036.htm.

2. $\quad$ Abbott Laboratories (2008b). Business and citizenship (LA1). http://www.abbott.com/global/url/content/en_US/40.10:10/general_content/General_Content_00036.htm.

3. Abbott Laboratories (2008c). Global product protection (PR1). http://www.abbott.com/global/url/content/en_US/40.53:53/general_content/General_Content_00148.htm.

4. Abbott Laboratories (2008d). GRI index. http://www.abbott.com/global/url/content/en_US/40.10.50:50/general_content/General_Content_00257.ht m.

5. $\quad$ Abbott Laboratories (2008e). Innovation to impact (PR1). http://www.abbott.com/global/url/content/en_US/40.10.15:15/general_content/General_Content_00418.ht $\underline{\mathrm{m}}$.

6. $\quad$ Abbott Laboratories (2008f). Note 8 - Litigation and environmental matters (EN28). http://www.abbott.com/static/content/microsite/annual_report/2008/11_note8-9.html.

7. Abbott Laboratories (2008g). Protecting patients and customers (PR1). http://www.abbott.com/global/url/content/en_US/40.50:50/general_content/General_Content_00264.htm.

8. Abbott Laboratories (2008h). Supply Chain Management (HR2). http://www.abbott.com/global/url/content/en_US/40.50.25:25/general_content/General_Content_00480.ht m. 
9. Adidas Group (2008a). Giving 110\%: our effort to be a responsible business in 2007. http://www.adidasgroup.com/en/SER2007/pdf/adidas_SER2007_report.pdf.

10. Adidas Group. (2008b). GRI index. http://www.adidas-group.com/en/SER2007/gri_index.asp.

11. Adidas Group(2010). 2009 Sustainability review: Team talk. http://www.adidas-group.com/en/SER2009/

12. AstraZeneca (2008a). Clinical Trials (PR1). http://www.astrazeneca.com/responsibility_archive/reportingperformance/gri-content-index/performance-indicators/\#.

13. AstraZeneca (2008b). Code of conduct (PR1). http://www.astrazeneca.com/responsibility_archive/reporting-performance/gri-content-index/performanceindicators/\#.

14. AstraZeneca (2008c). Community support policy (SO1). http://www.astrazeneca.com/responsibility_archive/reporting-performance/gri-content-index/performanceindicators/\#.

15. AstraZeneca International (2008d). Financial statements (EC1). http://www.astrazenecaannualreports.com/2009/financial_statements/index.html.

16. AstraZeneca International (2008e). GRI index. http://www.astrazeneca.com/search/?itemId=8472770.

17. AstraZeneca (2008f). In the global community (SO1). http://www.astrazenecaannualreports.com/2008/directors report/global_community/index.html.

18. AstraZeneca (2008g). Medicine (PR1). http://www.astrazenecaannualreports.com/2008/directors_report/resources_skills/medicines/index.html.

19. AstraZeneca (2008h). Patient safety (PR1). http://www.astrazeneca.com/responsibility archive/reportingperformance/gri-content-index/performance-indicators/\#.

20. AstraZeneca (2008i). Research and development (PR1). http://www.astrazenecaannualreports.com/2008/directors_report/resources_skills/r_and_d/safety_assessment.html.

21. AstraZeneca (2008j). SHE (safety, health and environment) governance \& compliance (EN28). http://www.astrazeneca.com/search/?itemId=8472591.

22. AstraZeneca (2008k). Stakeholder engagement (SO1). http://www.astrazeneca.com/responsibility archive/reporting-performance/gri-content-index/performanceindicators/\#.

23. Barclays (2008a). External assurance. http://www.barclays.com/sustainabilityreport07/external_assurance.html.

24. Barclays (2008b). GRI Tables. http://www.barclays.com/sustainabilityreport07/gri tables.html.

25. Barclays (2008c). Sustainability review 2007. http://www.barclays.com/sustainabilityreport07/.

26. Barclays (2009). Sustainability review 2008. http://group.barclays.com/cs/Satellite?blobcol=urldata\&blobheader=application\%2Fpdf\&blobheadername1 =Content-Disposition\&blobheadername2=MDT-

Type\&blobheadervalue $1=$ inline $\% 3 \mathrm{~B}+$ filename $\% 3$ DDownload-the-2008-Sustainability-SummaryReview.pdf\&blobheadervalue $2=$ abinary\%3B+charset\%3DUTF$\underline{8 \text { \&blobkey}=\text { id \&blobtable }=\text { MungoBlobs\&blobwhere }=1231864047348 \& \text { ssbinary }=\text { true }}$.

27. Baxter (2008a). 2008 sustainability report GRI index. http://sustainability.baxter.com/sustainability reporting/gri index.html.

28. Baxter (2008b). Direct impacts (EC1). http://sustainability.baxter.com/economic impacts/direct.html.

29. Baxter (2008c). Employees (LA1). http://sustainability.baxter.com/employees/index.html.

30. Baxter (2008d). Environmental compliance (EN28). http://sustainability.baxter.com/EHS/compliance/index.html.

31. Baxter (2008e). Environment, health and safety (SO1). http://sustainability.baxter.com/EHS/index.html.

32. Baxter (2008f). Managing supplier performance (HR2). http://sustainability.baxter.com/supply_chain/management.html.

33. Baxter (2008g). Product sustainability review (PR1). http://sustainability.baxter.com/product responsibility/R D and design/index.html.

34. Baxter (2008h). Regional employee breakdown (LA1). http://www.baxter.com/about_baxter/company_profile/corporate_overview.html\#regional_employee_break down.

35. Bayer (2008a). Creating value for the future (EC1). http://www.sustainability2008.bayer.com/en/thecompany.aspx? expand=1|2. 
36. Bayer (2008b). Economics (EC1).

http://www.sustainability2008.bayer.com/en/economics.aspx?expand=1|6.

37. Bayer (2008c). Economics (SO1). http://www.sustainability2008.bayer.com/en/economics.aspx?expand=6.

38. Bayer (2008d). Employees (LA1). http://www.sustainability2008.bayer.com/en/employees.aspx?expand=1|11.

39. Bayer (2008e). GRI index. http://www.sustainability2007.bayer.com/en/gri-index.aspx.

40. Bayer (2008f). Human rights (HR2). http://www.sustainability2008.bayer.com/en/humanrights.aspx? expand $=5 \mid 6$.

41. Bayer (2008g). Other provisions (EN28). http://www.annualreport2008.bayer.com/en/Otherprovisions.aspx.

42. Bayer (2008h). Our sustainability management (HR2). http://www.sustainability2008.bayer.com/en/sustainability-management.aspx?expand=5.

43. Bayer (2008i). Performance report. http://www.bayer.com/en/performance-report.aspx.

44. Bayer (2008j). Product Stewardship (PR1). http://www.sustainability2008.bayer.com/en/productstewardship.aspx? expand $=1$.

45. Bayer (2008k). Science for a better life: Sustainable development report 2007. http://www.sustainability2007.bayer.com/en/Sustainable-Development-Report-2007.pdfx.

46. Bayer (20081). Stakeholder dialogue (SO1). http://www.sustainability2008.bayer.com/en/stakeholderdialogue.aspx? expand $=1|2| 3$.

47. Bayer (2010). At a glance: Sustainability at Bayer 2009. http://www.bayer.com/en/Sustainability-at-Bayer2009.pdfx.

48. Bristol-Myers Squibb (2008a). Compliance and Remediation (EN28). http://www.bms.com/sustainability/environmental_performance/Pages/compliance_and_remediation.aspx.

49. Bristol-Myers Squibb (2008b). Economic performance (EC1). http://www.bms.com/sustainability/economic_responsibility/Pages/performance.aspx.

50. Bristol-Myers Squibb (2008c). Goals and performance indicators (EC1).

51. http://www.bms.com/sustainability/goals_key_indicators/Pages/goals_and_key_indicators.aspx.

52. Bristol-Myers Squibb (2008d). Global reporting initiative content index. http://www.bms.com/sustainability/global_reporting_initiative/Pages/index.aspx.

53. Ceres (2010). $21^{\text {st }}$ century corporation: The Ceres roadmap for sustainability. http://www.ceres.org/ceresroadmap.

54. Citigroup (2008a). Citizenship report 2007. http://www.citigroup.com/citi/citizen/data/citizen07_en.pdf.

55. Citigroup (2008b). GRI index. http://www.citigroup.com/citi/citizen/data/grireport.pdf.

56. Citigroup (2009). Citizenship report 2008. http://www.citigroup.com/citi/citizen/data/cr08.pdf.

57. Clarkson, P.M., Y. Li, G. D. Richardson \& F. P. Vasvari (2008). Revisiting the relation between environmental performance and environmental disclosure: an empirical analysis. Accounting, Organizations and Society. Volume 33, Issues 4-5, May-July 2008, pp. 303-327.

58. Elkington, J. (1997). Cannibals with forks: the triple bottom line of the $21^{\text {st }}$ century business. Capstone, Oxford.

59. Ford (2008a). Blueprint for sustainability. http://www.ford.com/microsites/sustainability-report-2007$\underline{08 / \text { default. }}$

60. Ford (2008b). GRI Content Index. http://www.ford.com/microsites/sustainability-report-2007-08/gri.

61. Ford (2010a). Blueprint for sustainability - Our future works (2008-09). http://www.ford.com/microsites/sustainability-report-2008-09/overview.

62. Ford (2010b). GRI Content Index http://www.ford.com/microsites/sustainability-report-2008-09/gri

63. Global Reporting Initiative (GRI, 2002). Sustainability reporting guidelines. http://www.globalreporting.org.

64. Global Reporting Initiative (GRI, 2004). GRI automotive sector supplement - Pilot version 1.0. http://www.globalreporting.org/NR/rdonlyres/70611BE2-F097-4550-AEC7D93B1A858D49/0/AutomotiveSectorSupplementPilot.pdf.

65. Global Reporting Initiative (GRI, 2006). Sustainability reporting G3 guidelines. http://www.globalreporting.org/NR/rdonlyres/ED9E9B36-AB54-4DE1-BFF25F735235CA44/0/G3_GuidelinesENU.pdf (in hardcopy); also available in on-line version at http://www.globalreporting.org/ReportingFramework/G3Online/. 
66. Global Reporting Initiative (GRI, 2007). Making the switch.

http://www.globalreporting.org/NR/rdonlyres/8F4781CA-BB96-4B68-8FBD-

A1CC3AA0E353/450/MakingtheSwitch.pdf.

67. Global Reporting Initiative (GRI, 2009a). Number of companies reporting sustainability performance high, yet still a minority.

http://www.globalreporting.org/NewsEventsPress/LatestPressReleases/2009/PressRelease_14_July_2006_ 1000GRIReports.htm.

68. Global Reporting Initiative (GRI, 2009b). Sustainability reporting guidelines and the financial services sector supplement. http://www.globalreporting.org/NR/rdonlyres/54B51A96-FDD0-4E5C-9F13FDC8C48AA209/2488/RGFSSS17finalcorrvers170209pdf.pdf.

69. GlaxoSmithKline (2008a). Access to medicines (SO1). http://www.gsk.com/responsibility/access/index.htm.

70. GlaxoSmithKline (2008b). Audits and Compliance (EN28). http://www.gsk.com/responsibility/environmental/audits-and-compliance.htm.

71. GlaxoSmithKline (2008c). Community investment (EC1). http://www.gsk.com/community/index.htm.

72. GlaxoSmithKline (2008d). Contribution to global health (SO1). http://www.gsk.com/responsibility/globalhealth/index.htm.

73. GlaxoSmithKline (2008e). Counterfeiting (PR1). http://www.gsk.com/responsibility/supplychain/counterfeiting.htm.

74. GlaxoSmithKline (2008f). GRI index. http://www.gsk.com/responsibility/downloads/gri08.pdf.

75. GlaxoSmithKline (2008g). Maintaining quality (PR1). http://www.gsk.com/responsibility/supplychain/maintaining-quality.htm.

76. GlaxoSmithKline (2008h). Monitoring and engagement (HR2). http://www.gsk.com/responsibility/supplychain/monitoring-and-engagement.htm.

77. GlaxoSmithKline (2008i). Our work with communities (SO1). http://www.gsk.com/community/index.htm.

78. GlaxoSmithKline (2008j). Patient safety (PR1). http://www.gsk.com/responsibility/researchpractices/patient-safety.htm.

79. Johnson \& Johnson (2008a). Global reporting initiative index. http://www.jnj.com/wps/wcm/connect/ad9170804f55661a9ec3be1bb31559c7/2008+Sustainability+Report. pdf?MOD=AJPERES, p. 36.

80. Johnson \& Johnson (2008b). Sustainability report 2008 (EC1). http://www.jnj.com/wps/wcm/connect/ad9170804f55661a9ec3be1bb31559c7/2008+Sustainability+Report. pdf?MOD=AJPERES, pp. 8-9, 15-16, 32-33.

81. Johnson \& Johnson (2008c). Sustainability report 2008 (EN28). http://www.jnj.com/wps/wcm/connect/ad9170804f55661a9ec3be1bb31559c7/2008+Sustainability+Report. pdf?MOD=AJPERES, p. 22.

82. Johnson \& Johnson (2008d). Sustainability report 2008 (HR2). http://www.jnj.com/wps/wcm/connect/ad9170804f55661a9ec3be1bb31559c7/2008+Sustainability+Report. pdf?MOD=AJPERES, p. 17.

83. Johnson \& Johnson (2008e). Sustainability report 2008 (PR1). http://www.jnj.com/wps/wcm/connect/ad9170804f55661a9ec3be1bb31559c7/2008+Sustainability+Report. pdf?MOD=AJPERES, p. 12.

84. Johnson \& Johnson (2008f). Sustainability report 2008 (SO1). http://www.jnj.com/wps/wcm/connect/ad9170804f55661a9ec3be1bb31559c7/2008+Sustainability+Report. pdf?MOD=AJPERES, pp. 3, 5, 16-17.

85. KPMG (2008). International survey of corporate responsibility reporting 2008. http://www.kpmg.com/Global/en/IssuesAndInsights/ArticlesPublications/Documents/Internationalcorporate-responsibility-survey-2008.pdf.

86. KPMG \& SustainAbility (2008). Count me in: the reader's take on sustainability reporting. http://www.globalreporting.org/NR/rdonlyres/3F57ACC8-60D0-48F0-AF28527F85A2A4B4/0/CountMeIn.pdf.

87. Merck (2007a). Key performance indicators. http://www.merck.com/corporate-responsibility/summarydata-resources/kpis-gri-atmi-mdgs/gri-indicators.html. 
88. Merck (2007b). Listening, responding and working toward a healthier future: Corporate responsibility 2006-2007 report. http://www.merck.com/corporate-responsibility/docs/cr2006-2007.pdf.

89. Merck (2008a). Advancing the dialogue towards a healthier future: Corporate responsibility report 2008. http://merck-ut.merck.com/corporate-responsibility/docs/cr2008.pdf.

90. Merck (2008b). Corporate responsibility 2008 report (EC1). http://merck-ut.merck.com/corporateresponsibility/docs/cr2008.pdf, p. 4.

91. Merck (2008c). Corporate responsibility 2008 report (EN28). http://merck-ut.merck.com/corporateresponsibility/docs/cr2008.pdf, p.38.

92. Merck (2008d). Corporate responsibility 2008 report (HR2). http://merck-ut.merck.com/corporateresponsibility/docs/cr2008.pdf, p.54.

93. Merck (2008e). Corporate responsibility 2008 report (LA1). http://merck-ut.merck.com/corporateresponsibility/docs/cr2008.pdf, p.51.

94. Merck (2008f). Corporate responsibility 2008 report (PR1). http://merck-ut.merck.com/corporateresponsibility/docs/cr2008.pdf, p.53.

95. Merck (2008g). Corporate responsibility2008 report (SO1). http://merck-ut.merck.com/corporateresponsibility/docs/cr2008.pdf, p.4.

96. Nike (2007a). Innovate for a better world: Nike FY 05/06 corporate responsibility report. http://www.nikeresponsibility.com/pdfs/color/Nike FY05 06_CR Report_C.pdf.

97. Nike (2007b). Guidelines and principles index. Innovate for a better world: Nike FY 05/06 corporate responsibility report. http://www.nikeresponsibility.com/pdfs/color/13 Nike_CRR_GRI_Index_C.pdf.

98. Nike (2010). Corporate responsibility report FY 0708 09. http://www.nikebiz.com/crreport/.

99. Novartis (2008a). Novartis 2008 GRI report. http://www.corporatecitizenship.novartis.com/downloads/managing-cc/novartis_2008_gri_report.pdf, p. 3.

100. Novartis (2008b). Novartis 2008 GRI report (EC1). http://www.corporatecitizenship.novartis.com/downloads/managing-cc/novartis_2008_gri_report.pdf, $p$. 37.

101. Novartis (2008c). Novartis 2008 GRI report (EN28). http://www.corporatecitizenship.novartis.com/downloads/managing-cc/novartis 2008 gri report.pdf, $p$. 38.

102. Novartis (2008d). Novartis 2008 GRI report (HR2). http://www.corporatecitizenship.novartis.com/downloads/managing-cc/novartis_2008_gri_report.pdf, p. 54.

103. Novartis (2008e). Novartis 2008 GRI report (LA1). http://www.corporatecitizenship.novartis.com/downloads/managing-cc/novartis_2008_gri_report.pdf, p. 55.

104. Novartis (2008f). Novartis 2008 GRI report (PR1). http://www.corporatecitizenship.novartis.com/downloads/managing-cc/novartis_2008_gri_report.pdf, p. 61.

105. Novartis (2008g). Novartis 2008 GRI report (SO1). http://www.corporatecitizenship.novartis.com/downloads/managing-cc/novartis_2008_gri_report.pdf, p. 64.

106. Novo Nordisk (2009a). Global reporting initiative. http://annualreport.novonordisk.com/governance-andreporting/global-reporting-initiative.aspx.

107. Novo Nordisk (2009b). Facts and figures (LA1). http://www.novonordisk.com/about us/default.asp.

108. Novo Nordisk (2009c). Global reporting initiative (EN28).

http://annualreport.novonordisk.com/governance-and-reporting/global-reporting-initiative.aspx.

109. Novo Nordisk (2009d). Human rights (HR2). http://annualreport.novonordisk.com/social/humanrights.aspx.

110. Novo Nordisk (2009e). Quality (PR1). http://annualreport.novonordisk.com/financial-andeconomics/quality.aspx.

111. Novo Nordisk (2009f). Responsible sourcing (HR2). http://annualreport.novonordisk.com/social/responsible-sourcing.aspx.

112. Novo Nordisk (2009g). Socio-economics (EC1). http://annualreport.novonordisk.com/financial-andeconomics/socio-economics.aspx. 
113. Pedrini, M. (2007). Human capital convergences in intellectual capital and sustainability reports. Journal of Intellectual Capital. Vol. 8, Issue 2; pp. 346.

114. Pfizer (2008a). Company profile (EC1). http://www.pfizer.com/responsibility/cr_report/profile.jsp.

115. Pfizer (2008b). Employees \& community (EC1). http://www.pfizer.com/responsibility/cr_report/colleagues.jsp.

116. Pfizer (2008c). Environment, health and safety (EN28; HR2). http://www.pfizer.com/responsibility/cr_report/environment.jsp.

117. Pfizer, Inc. (2008d). GRI Index. http://www.pfizer.com/responsibility/cr_report/gri.jsp.

118. Pfizer (2008e). Lobbying and governance (EC1). http://www.pfizer.com/responsibility/cr_report/ob_governance.jsp.

119. Pfizer (2008f). Patient safety/counterfeiting(PR1). http://www.pfizer.com/responsibility/cr_report/safety.jsp.

120. Pfizer (2008g). Product Stewardship (PR1). http://www.pfizer.com/responsibility/cr_report/environment.jsp.

121. Pfizer (2008h). Research \& development (PR1). http://www.pfizer.com/responsibility/cr_report/research.jsp.

122. Roche (2009a). Global reporting initiative (GRI) content index 2009. http://www.roche.com/gb09 gri.pdf.

123. Roche (2009b). Global reporting initiative (GRI) content index 2009 (EC1). http://www.roche.com/gb09_gri.pdf.

124. Roche (2009c). Global reporting initiative (GRI) content index 2009 (EN28). http://www.roche.com/gb09 gri.pdf, p. 120 of the 2009 Business Report.

125. Roche (2009d). Global reporting initiative (GRI) content index 2009 (HR2). http://www.roche.com/gb09_gri.pdf, pp. 12, 93-94, 96 of the 2009 Business Report.

126. Roche (2009e). Global reporting initiative (GRI) content index 2009 (LA1). http://www.roche.com/gb09_gri.pdf, p. 105 of the 2009 Business Report.

127. Roche (2009f). Global reporting initiative (GRI) content index 2009 (PR1). http://www.roche.com/gb09 gri.pdf, pp. 93-94, 101-102 of the 2009 Business Report.

128. Roche (2009g). Global reporting initiative (GRI) content index 2009 (SO1). http://www.roche.com/gb09 gri.pdf, pp. 112-113 of the 2009 Business Report.

129. sanofi-aventis (2008a). Summary. http://en.sanofi-aventis.com/binaries/RDD_2008 EN tcm28-24844.pdf.

130. sanofi-aventis (2008b). 2008 Sustainability report (HR2). http://en.sanofiaventis.com/binaries/RDD_2008_EN_tcm28-24844.pdf, p. 25.

131. Sanofi-aventis (2008c). 2008 Sustainability report (LA1). http://en.sanofiaventis.com/binaries/RDD_2008_EN_tcm28-24844.pdf, p. 38.

132. sanofi-aventis (2008d). 2008 Sustainability report (PR1). http://en.sanofiaventis.com/binaries/RDD_2008_EN_tcm28-24844.pdf, p. 32.

133. sanofi-aventis (2008e). 2008 Sustainability report (SO1). http://en.sanofiaventis.com/binaries/RDD_2008_EN_tcm28-24844.pdf, p. 22.

134. Sherman, W. R. (2008). The Global Reporting Initiative: What Value is Added? International Business \& Economics Journal. Vol. 8, No. 5, pp. 9-21.

135. Sherman, W. R. (2009). Making Triple Bottom Line Reporting Comparable: Adoption of the GRI G3 Framework. Presented at 2009 Oxford Business \& Economics Conference. June 25, 2009. Oxford, UK.

136. Volkswagen (2008). Sustainability Report 2007/2008: We are moving into the future responsibly. http://www.volkswagenag.com/vwag/vwcorp/info center/en/publications/2007/09/sustainability report.bin.acq/qual-BinaryStorageItem.Single.File/sustainability report 07-08 engl.pdf.

137. Volkswagen (2010) Sustainability Report 2009/2010: Driving ideas. http://www.volkswagenag.com/vwag/nb09bis10/content/en/homepage.html. 
Table 1: Reporting level \& verification

\begin{tabular}{|c|c|c|c|c|}
\hline & Application & GRI Content & & \\
\hline Company & Level & Verification & Country & Industry \\
\hline Ford Motor Company & $\mathrm{A}$ & Self-declared & USA & Automotive \\
\hline Volkswagen & $\mathrm{A}+$ & GRI-checked & Germany & Automotive \\
\hline Barclays & $\mathrm{B}+$ & Third-party-checked & UK & Financial Services \\
\hline Citigroup & $\mathrm{B}$ & Self-declared & USA & Financial Services \\
\hline Bayer AG & $\mathrm{A}+$ & GRI-checked & Germany & Pharmaceuticals \\
\hline Merck \& Co & $\mathrm{B}$ & GRI-checked & USA & Pharmaceuticals \\
\hline \multirow[t]{2}{*}{ Adidas Group } & $\mathrm{C}$ in 2006 & Self-declared & Germany & Sporting Goods \\
\hline & None in 2009 & & & \\
\hline \multirow[t]{2}{*}{ Nike } & NA in 2006 & Self-declared & USA & Sporting Goods \\
\hline & B in 2009 & & & \\
\hline
\end{tabular}

Table 2: Common Core Indicators Reported

\begin{tabular}{|l|c|c|}
\hline & $\mathbf{2 0 0 6 - 0 7}$ & $\mathbf{2 0 0 8 - 0 9}$ \\
\hline Ford vs. Volkswagen: & $70 \%$ & $82 \%$ \\
\hline Citigroup vs. Barclays: & $26 \%$ & $20 \%$ \\
\hline Merck vs. Bayer: & $80 \%$ & $84 \%$ \\
\hline Nike vs. Adidas: & $28 \%$ & $0 \%$ \\
\hline
\end{tabular}

Note: Even with common indicators, the units of measurement used frequently varies between companies 


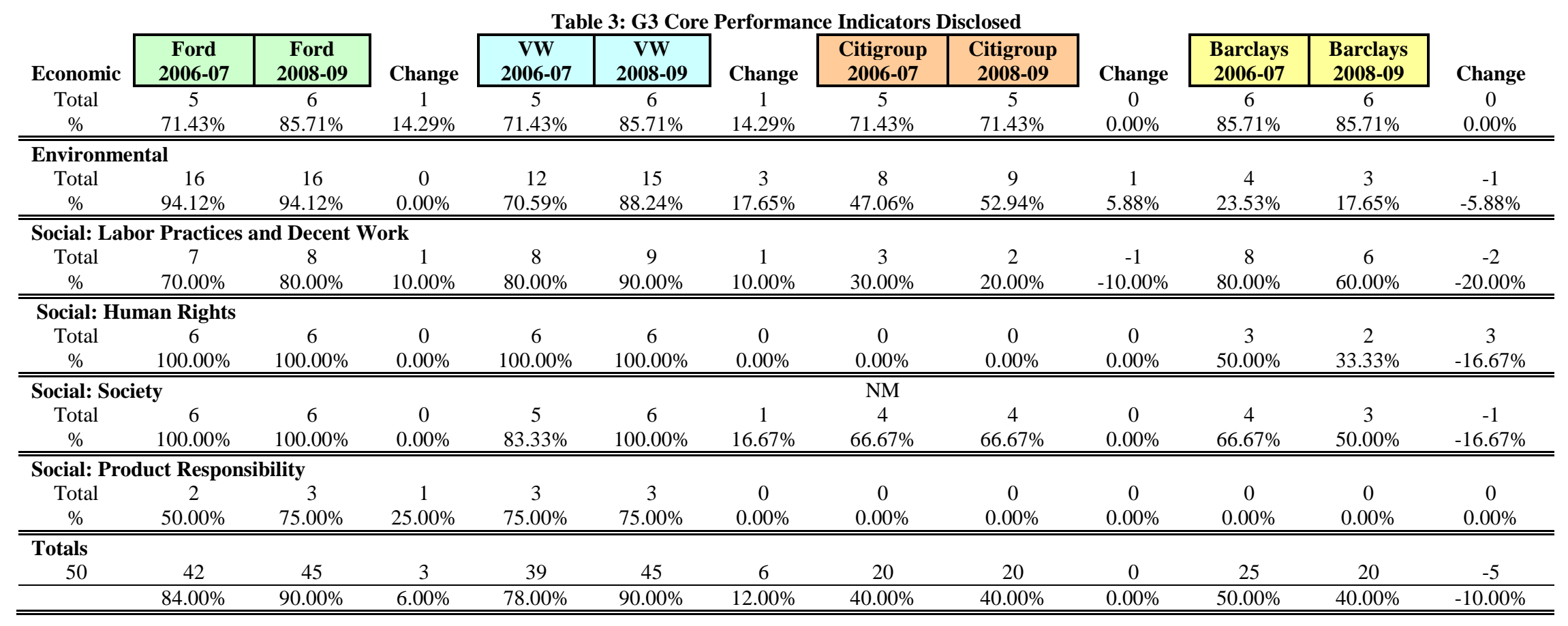




\begin{tabular}{|c|c|c|c|c|c|c|c|c|c|c|c|c|}
\hline Economic & $\begin{array}{c}\text { Merck } \\
\text { 2006-07 }\end{array}$ & $\begin{array}{c}\text { Merck } \\
\text { 2008-09 }\end{array}$ & Change & $\begin{array}{c}\text { Bayer } \\
\text { 2006-07 } \\
\end{array}$ & $\begin{array}{c}\text { Bayer } \\
\text { 2008-09 }\end{array}$ & Change & $\begin{array}{c}\text { Nike } \\
2006-07 \\
\end{array}$ & $\begin{array}{c}\text { Nike } \\
\text { 2008-099 } \\
\end{array}$ & Change & \begin{tabular}{|c|} 
Adidas \\
2006-07 \\
\end{tabular} & $\begin{array}{c}\text { Adidas } \\
\text { 2008-09 } \\
\end{array}$ & Change \\
\hline Total & 5 & 6 & 1 & 7 & 7 & 0 & 4 & 4 & 0 & 1 & 0 & -1 \\
\hline$\%$ & $71.43 \%$ & $85.71 \%$ & $14.29 \%$ & $100.00 \%$ & $100.00 \%$ & $0.00 \%$ & $57.14 \%$ & $57.14 \%$ & $0.00 \%$ & $14.29 \%$ & $0.00 \%$ & $-14.29 \%$ \\
\hline \multicolumn{13}{|c|}{ Environmental } \\
\hline Total & 12 & 14 & 2 & 17 & 17 & 0 & 8 & 10 & 2 & 2 & 0 & -2 \\
\hline$\%$ & $70.59 \%$ & $82.35 \%$ & $11.76 \%$ & $100.00 \%$ & $100.00 \%$ & $0.00 \%$ & $47.06 \%$ & $58.82 \%$ & $11.76 \%$ & $11.76 \%$ & $0.00 \%$ & $-11.76 \%$ \\
\hline \multicolumn{13}{|c|}{ Social: Labor Practices and Decent Work } \\
\hline Total & 9 & 8 & -1 & 9 & 9 & 0 & 3 & 3 & 0 & 1 & 0 & -1 \\
\hline$\%$ & $90.00 \%$ & $80.00 \%$ & $-10.00 \%$ & $90.00 \%$ & $90.00 \%$ & $0.00 \%$ & $30.00 \%$ & $30.00 \%$ & $0.00 \%$ & $10.00 \%$ & $0.00 \%$ & $-10.00 \%$ \\
\hline \multicolumn{13}{|c|}{ Social: Human Rights } \\
\hline Total & 5 & 5 & 0 & 6 & 6 & 0 & 6 & 6 & 0 & 4 & 0 & -4 \\
\hline$\%$ & $83.33 \%$ & $83.33 \%$ & $0.00 \%$ & $100.00 \%$ & $100.00 \%$ & $0.00 \%$ & $100.00 \%$ & $100.00 \%$ & $0.00 \%$ & $66.67 \%$ & $0.00 \%$ & $-66.67 \%$ \\
\hline \multicolumn{13}{|c|}{ Social: Society } \\
\hline Total & 6 & 6 & 0 & 6 & 6 & 0 & 2 & 2 & 0 & 0 & 0 & 0 \\
\hline$\%$ & $100.00 \%$ & $100.00 \%$ & $0.00 \%$ & $100.00 \%$ & $100.00 \%$ & $0.00 \%$ & $33.33 \%$ & $33.33 \%$ & $0.00 \%$ & $0.00 \%$ & $0.00 \%$ & $0.00 \%$ \\
\hline \multicolumn{13}{|c|}{ Social: Product Responsibility } \\
\hline Total & 4 & 4 & 0 & 4 & 4 & 0 & 1 & 1 & 0 & 1 & 0 & -1 \\
\hline$\%$ & $100.00 \%$ & $100.00 \%$ & $0.00 \%$ & $100.00 \%$ & $100.00 \%$ & $0.00 \%$ & $25.00 \%$ & $25.00 \%$ & $0.00 \%$ & $25.00 \%$ & $0.00 \%$ & $-25.00 \%$ \\
\hline \multicolumn{13}{|l|}{ Totals } \\
\hline 50 & 41 & 43 & 2 & 49 & 49 & 0 & 24 & 26 & 2 & 9 & 0 & -9 \\
\hline & $82.00 \%$ & $86.00 \%$ & $4.00 \%$ & $98.00 \%$ & $98.00 \%$ & $0.00 \%$ & $48.00 \%$ & $52.00 \%$ & $4.00 \%$ & $18.00 \%$ & $0.00 \%$ & $-18.00 \%$ \\
\hline
\end{tabular}


Table 4: GRI Core Performance Indicators - A Sample

Economic

- $\quad$ *EC1: Direct economic value-generated and distributed, including revenues, operating costs, employee compensation, donations and other community investments, retained earnings and payments to capital providers and customers

- $\quad$ EC2: Financial implications and other risks and opportunities for the organization's activities due to climate change

Environmental

- $\quad$ EN1: Materials used by weight or volume

- $\quad$ EN2: Percentage of materials used that are recycled input materials

- $\quad$ EN3: Direct energy consumption by primary energy source

- $\quad$ EN4: Indirect energy consumption by primary source

- $\quad$ EN16: Total direct and indirect greenhouse gas emissions by weight

- $\quad$ *EN28: Monetary value of significant fines and total number of non-monetary sanctions for non-compliance with environmental laws and regulations

Society

- $\quad$ *SO1: Nature, scope, and effectiveness of any programs and practices that assess and manage the impacts of operations on communities, including entering, operating, and exiting

- SO4: Actions taken in response to incidents of corruption

- $\quad$ SO8: Monetary value of significant fines and total number of non-monetary sanctions for non-compliance with laws and regulations

\section{Human Rights}

- HR1: Percentage and total number of significant investment agreements that include human rights clauses or that have undergone human rights screening

- $\quad$ *HR2: Percentage of significant suppliers that have undergone screening on human rights and actions taken

- HR4: Total number of incidents of discrimination and actions taken

\section{Labor Practices \& Decent Work}

- $\quad$ *LA1: Total workforce by employment type, employment contract, and region

- LA2: Total number and rate of employee turnover by age group, gender, and region

- $\quad$ LA 10: Average hours of training per year per employee by employee category

- $\quad$ LA14: Ratio of basic salary of men to women by employee category

Product Responsibility

- $\quad$ *PR1: Life cycle stages in which health and safety impacts of products and services are assessed for improvement, and percentage of significant products and service categories subject to such procedures

- $\quad$ PR9: Monetary value of significant fines for noncompliance with laws and regulations concerning the provision and use of products and services

* Selected for further analysis 
Table 5: Selected Pharmaceutical Companies

Company Adherence Level

Abbott

Baxter

Bayer AG

Bristol-Myers Squibb Company

GlaxoSmithKline

Johnson \& Johnson

Merck and Co.

Novartis

Novo Nordisk

Pfizer

Roche

Sanofi-Aventis
Undeclared $^{1}$

$\mathrm{B}+$

Verification

Third-party-checked

Self-Declared

GRI-checked

A+

A

A+

Undeclared $^{2}$

B

A+

A+

B

A+

Undeclared $^{3}$
Third-party-checked

Self-Declared

N/A

GRI-checked

GRI-checked

Self-Declared

Self-Declared

GRI-checked N/A
Country

USA

UK

USA

Germany

UK

UK

USA

USA

Switzerland

Denmark

USA

Switzerland France

Table 6: Comparability of G3 Reports in Pharmaceutical Industry on Selected Indicators

\begin{tabular}{|c|c|c|c|c|c|}
\hline & $\begin{array}{c}\text { Fully } \\
\text { Reported }\end{array}$ & $\begin{array}{l}\text { Partially } \\
\text { Reported }\end{array}$ & $\begin{array}{c}\text { Not } \\
\text { Reported }\end{array}$ & \% Reported & \% Not Reported \\
\hline \multicolumn{6}{|c|}{ Economic } \\
\hline $\mathrm{EC} 1$ & 12 & 0 & 1 & $92 \%$ & $8 \%$ \\
\hline $\mathrm{EC} 2$ & 13 & 0 & 0 & $100 \%$ & $0 \%$ \\
\hline \multicolumn{6}{|c|}{ Environmental } \\
\hline EN1 & 7 & 0 & 6 & $54 \%$ & $46 \%$ \\
\hline EN2 & 5 & 0 & 8 & $38 \%$ & $62 \%$ \\
\hline EN3 & 13 & 0 & 0 & $100 \%$ & $0 \%$ \\
\hline EN4 & 10 & 1 & 2 & $85 \%$ & $15 \%$ \\
\hline EN16 & 13 & 0 & 0 & $100 \%$ & $0 \%$ \\
\hline EN28 & 12 & 0 & 1 & $92 \%$ & $8 \%$ \\
\hline \multicolumn{6}{|c|}{ Social: Labor Practices and Decent Work } \\
\hline LA1 & 7 & 1 & 5 & $62 \%$ & $38 \%$ \\
\hline LA2 & 2 & 3 & 8 & $38 \%$ & $62 \%$ \\
\hline LA10 & 6 & 1 & 6 & $54 \%$ & $46 \%$ \\
\hline LA14 & 0 & 3 & 10 & $23 \%$ & $77 \%$ \\
\hline \multicolumn{6}{|c|}{ Social: Human Rights } \\
\hline HR1 & 5 & 1 & 7 & $46 \%$ & $54 \%$ \\
\hline HR2 & 11 & 1 & 1 & $92 \%$ & $8 \%$ \\
\hline HR4 & 5 & 1 & 7 & $46 \%$ & $54 \%$ \\
\hline \multicolumn{6}{|c|}{ Social: Society } \\
\hline $\mathrm{SO} 1$ & 8 & 1 & 4 & $69 \%$ & $31 \%$ \\
\hline $\mathrm{SO} 4$ & 8 & 0 & 5 & $62 \%$ & $38 \%$ \\
\hline SO8 & 8 & 0 & 5 & $62 \%$ & $38 \%$ \\
\hline \multicolumn{6}{|c|}{ Social: Product Responsibility } \\
\hline PR1 & 12 & 0 & 1 & $92 \%$ & $8 \%$ \\
\hline PR9 & 7 & 0 & 6 & $54 \%$ & $46 \%$ \\
\hline
\end{tabular}

\footnotetext{
${ }^{1}$ Abbott has not adopted the G3 Guidelines. Instead, its report "refers" the G3 Guidelines and provides its own index which it compares against the GRI Guidelines.

http://www.abbott.com/global/url/content/en US/40.10.40:40/general content/General Content 00053.htm.

${ }^{2} \mathrm{~J} \&$ J has not adopted the G3 Guidelines. However, "consideration was given" to the G3 Guidelines and "an index with references to G3 indicators" is included in its report. http://www.myvirtualpaper.com/doc/jnj/JnJ 2008/2009060901/ .

3 sanofi-aventis' sustainability report is "designed according to the Global Reporting Initiative (GRI) 3 Guidelines" and reports on some of the indicators the company feels are most relevant.

http://en.sanofi-aventis.com/binaries/RDD 2008 EN tcm28-24844.pdf.
} 
NOTES 